\section{Hipotaxe adverbial e suas funções textual-discursivas no gênero resposta argumentativa}

\author{
The adverbial clauses \\ and their textual- \\ discursive functions in the \\ argumentative answer genre
}

Fátima Christina CALICCHIO (UEM) fatima.calicchio@hotmail.com
CALICCHIO, Fátima Christina.

Hipotaxe adverbial e suas

funções textual-discursivas no

gênero resposta argumentativa.

Entrepalavras, Fortaleza, v. 6, n. 2, p. 29-53, jul./dez. 2016.

Resumo: Propomos neste trabalho analisar como a hipotaxe adverbial pode contribuir para a construção da argumentatividade do gênero resposta argumentativa. Para isso, selecionamos como objeto de análise as produções textuais prototípicas dos candidatos ao vestibular de verão da UEM/2011. Levando em consideração o panorama teórico do funcionalismo, a hipótese a ser explorada neste trabalho corresponde à investigação das funções textualdiscursivas das orações adverbiais que funcionam como valor de guia, ponte de transição, moldura, foco, função tópica, dentre outras funções, na articulação de orações que podem contribuir para a construção da argumentatividade do gênero resposta argumentativa. Como aporte teórico, aliamos estudos de funcionalistas, como Mann \& Thompson (1988); Matthiessen \& Thompson (1988), à Teoria da Estrutura Retórica do Texto. De acordo com essa teoria, as relações retóricas dão coerência ao discurso, conferindo unidade e permitindo que o produtor atinja seus propósitos com o texto que produziu, ou seja, essa teoria fundamenta-se no principio de que, no texto, além das proposições explicitas, ou enunciados explícitos, emergem 
V. 6 (2) 29-53 jul/dez 2016

30

proposições implícitas, que se caracterizam como o significado que emerge entre duas porções de texto. Somam-se a esse enfoque os pressupostos de Decat (2009), de Neves $(1997,2000)$ e as postulações sobre gênero defendidas por Bakhtin (2000).

Palavras-chave: Hipotaxe adverbial. Função textual-discursiva. Gênero resposta argumentativa.

\begin{abstract}
We aim in this paper to analyze how adverbial hypotaxis can contribute to the construction of argumentativeness of genre argumentative response. We selected as the object of analysis the textual productions of candidates for the entrance summer exam UEM/2011. Considering the theoretical panorama, the functionalism, the hypothesis to be explored in this paper corresponds to the investigation of textualdiscursive functions of adverbial clauses that function as guide value, transitional bridge, frame, focus, topical function among other functions in conjunction causes that can contribute to the construction of argumentativeness genre of argumentative response. As a theoretical contribution, we combine studies of functionalist as Mann \& Thompson (1988); Matthiessen \& Thompson (1988), Theory of Rhetoric Text Structure. According to this theory, the rhetorical relations give coherence to the discourse, giving unity and allowing the producer to achieve its purposes with the text produced, that is, the theory is based on the principle that the text, in addition to the explicit propositions or explicit statements emerge implied propositions characterized as meaning that emerges between two portions of text. Added to this approach: the assumptions Decat (2009), Neves (1997, 2000) and postulations about genre according to the view of Bakhtin (2000).
\end{abstract}

Keywords: Hypotaxis adverbial. Textual-discursive function. Answer Argumentative genre.

\title{
Introdução
}

Ao consideramos que a língua é um instrumento que se presta à interação social e que a descrição de seu funcionamento pode revelar muito a respeito do contexto comunicativo em que é utilizada, objetivamos, de uma maneira geral, neste estudo, investigar se a função textual-discursiva das orações adverbiais presentes na articulação de orações pode contribuir para a construção da argumentatividade do gênero resposta argumentativa.

Consoante à abordagem funcionalista da linguagem, o presente trabalho parte da hipótese de que a função textual-discursiva está na base do uso das orações adverbiais, ao exibir não só relações semânticas como tempo, modo, causa/motivo, concessão, condição etc., mas também funções textual-discursivas que podem propiciar o entendimento da intenção do usuário da língua ao fazer as combinações entre as orações na organização do texto (DECAT, 2009, p. 116).

De uma maneira especifica, objetiva-se verificar qual a função textual-discursiva desempenhada pela hipotaxe adverbial no gênero resposta argumentativa. Portanto, esta pesquisa justifica-se pelo 
interesse em evidenciar a importância de estudos que se preocupem com os processos de articulação de orações ${ }^{1}$, considerando o contexto de uso, como o papel do usuário da língua na organização de seu discurso e sua intenção comunicativa. Isto é, a partir de um olhar funcionalista, esta pesquisa contemplará, em suas análises, além do nível sintático, o contexto, bem como critérios semânticos e pragmáticos ${ }^{2}$.

\section{A teoria funcionalista}

O funcionalismo é uma corrente linguística que leva em conta fatores interacionais, pragmáticos ${ }^{3}$ e propõe que a língua sofre influência de fatores extralinguísticos, isto é, essa vertente defende a concepção de que a sintaxe não é autônoma em relação à semântica e à pragmática (BUTLER, 2005). Em consonância com o que afirma Butler (2005), Antonio (2009) ressalta que, no paradigma funcional, as expressões linguísticas não são estudadas isoladamente, mas levam em conta os propósitos para os quais foram utilizadas nos textos em que ocorrem.

Para Neves (2010), o funcionalismo é uma teoria que se liga aos fins a que servem as unidades linguísticas, em outras palavras, um estudo pelo viés funcionalista vincula a língua a um evento comunicativo, uma vez que estarão envolvidos, em um determinado contexto de uso do sistema linguístico, aspectos sintáticos, semânticos e pragmáticos.

A respeito da necessidade de se estudar a língua priorizando análises de seu funcionamento em contextos sociais de interação, Dik (1989) concebe a linguagem, acima de tudo, como um instrumento de interação social entre seres humanos. Esse linguista propôs, em sua Gramática Funcional (GF), um modelo de interação verbal por meio da língua, considerada estruturada e cooperativa; estruturada porque é governada por regras, por normas e por convenções; cooperativa, porque precisa de, no mínimo, dois falantes da língua para atingir os objetivos comunicativos. Vejamos esse funcionamento que será explicitado no esquema a seguir, proposto por Dik (1989, p. 8).

1 Nesta pesquisa, entendemos articulação de orações como a forma com que o usuário combina ou articula as orações no português em uso.

2 Neste estudo, tomamos a pragmática como a teoria do uso linguístico, isto é, teoria que reconhece o uso da língua e o modo como ela é empregada na interação verbal, não estabelecendo a dicotomia entre o que é interno e externo à língua (MARTELOTTA, 2009).

3 São os fatores extralinguísticos de uso social da língua como: contexto situacional, os participantes da cena comunicativa, o conhecimento das normas e convenções linguísticas e sociais pertinentes ao contexto em questão, a atribuição de papeis e as funções de cada um dos envolvidos (MARTELOTTA, 2009, p. 90). 
V. 6 (2)

29-53

jul/dez

2016

Figura 1 - Modelo de interação Verbal - Modelo extraído de CALICCHIO (2014)

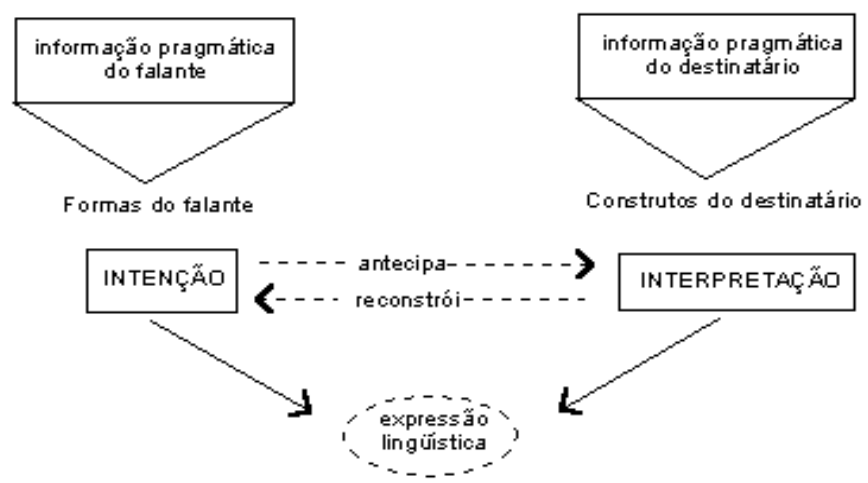

O modelo de interação verbal proposto por Dik tem por objetivo explicar o papel da expressão linguística na comunicação. Nesse modelo, o falante e o destinatário compartilham a informação pragmática. Esse modelo de interação verbal é motivado por essa informação compartilhada e a expressão linguística é produzida em função da intenção do falante, da informação pragmática do falante e da antecipação que ele faz da interpretação do destinatário. Este, por sua vez, interpreta a expressão linguística em função de sua informação pragmática e de suposições sobre a intenção comunicativa do falante.

Como se pode observar, o modelo de interação verbal de Dik (1989) pressupõe, em sua gramática (GF), que a sintaxe, a semântica e a pragmática não podem ser tratadas de maneira autônoma. Portanto, com base na proposta de Dik (2009), pode-se constatar a importância de se analisar a língua no contexto comunicativo em que ela ocorre.

De acordo, ainda, com essa perspectiva, outra contribuição aos estudos de base funcionalista surge a partir dos trabalhos de Hengeveld (2004, 2005) e Hengeveld \& Mackenzie (2008). Esses autores propõem uma ampliação dos estudos da Gramática Funcional de Dik (1989, 1997), Surge, então, a Gramática Discursivo-Funcional (GDF), com uma formulação de gramática que incorpora o componente discursivo.

A GDF propõe uma teoria focalizando análises de unidades textuais menores, iguais ou maiores que a oração, num modelo de organização descendente (Top Down). Essa perspectiva defende que a comunicação interpessoal é promovida por meio de discursos e não de orações isoladas. É inegável, portanto, a contribuição dos trabalhos dos autores da GDF para o Funcionalismo.

Interessante é destacar que, sob o rótulo do funcionalismo, existem várias vertentes, contudo neste artigo ${ }^{4}$ pretendemos relacionar

4 As discussões apresentadas neste artigo é um recorte de minha dissertação de 
o fenômeno gramatical da articulação de orações, Hipotaxe adverbial, à estrutura organizacional do texto. Por sua vez, a análise das ocorrências das redações que integram nosso corpus leva em conta as relações estabelecidas entre as porções do texto, bem como a função das porções do texto com os objetivos discursivos.

Nesse sentido, para que possamos oferecer uma alternativa sobre o estudo da articulação de orações, especificamente, da hipotaxe adverbial e sua função textual-discursiva, e das ações que se realizam na organização do texto, adotamos a Teoria da Estrutura Retórica (RST, de agora em diante), que possibilita descrever, caracterizar e analisar a organização textual.

\section{Teoria da Estrutura Retórica (Rhetorical Structure Theory - RST)}

De acordo com Mann e Thompson (1988); Matthiessen e Thompson (1988); Mann, Matthiessen e Thompson (1992), a RST é uma teoria descritiva que tem por objetivo o estudo da organização dos textos, caracterizando as relações que se estabelecem entre as partes do texto.

Segundo a RST, além do conteúdo proposicional explícito veiculado pelas orações de um texto, há proposições implícitas, chamadas proposições relacionais, que surgem das relações que se estabelecem entre porções do texto. Conforme os estudiosos da RST, as proposições relacionais dão coerência ao texto, conferindo unidade e permitindo que o produtor atinja seus propósitos com o texto que produziu.

\section{Os tipos de relações e suas definições}

De acordo com a RST, Mann e Thompson (1988) estabelecem uma lista de vinte e cinco relações, após a análise de centenas de textos, por meio dessa teoria. Essa lista não representa um rol fechado, mas um grupo de relações suficientes para descrever a maioria dos textos.

Mann e Thompson (1988) apresentam a seguinte divisão para as funções globais das relações: (i) Funções que dizem respeito ao assunto, que têm como efeito levar o enunciatário a reconhecer a relação em questão: elaboração, circunstância, solução, causa volitiva, resultado volitivo, causa não volitiva, resultado não volitivo, propósito, condição, 
V. 6 (2)

29-53

jul/dez

2016

interpretação, meio, avaliação, reafirmação, resumo, sequência, contraste. (ii) Funções que dizem respeito à apresentação da relação, que têm como efeito aumentar a inclinação do enunciatário a agir de acordo com o conteúdo do núcleo, concordar com o conteúdo do núcleo: apresentação, motivação, antítese, background, competência, evidência, justificativa, concessão, preparação.

Segundo os pressupostos teóricos da RST, as porções de um texto se organizam em informações nucleares e informações satélites. A porção núcleo é representada pela letra $\mathrm{N}$ e a satélite, pela letra $\mathrm{S}$. As porções nucleares são responsáveis pelas informações principais e as satélites, consideradas porções acessórias, pois auxiliam na compreensão e na aceitação das informações. Assim, os textos são formados por porções textuais hierarquicamente organizadas entre si, e as relações que se estabelecem podem ser de dois tipos: a) Relações núcleo-satélite: uma porção do texto (satélite) é ancilar da outra (núcleo), como na figura 2 , na qual um arco vai da porção que serve de subsídio para a porção que funciona como núcleo. b) Relações multinucleares: uma porção do texto não é ancilar da outra, sendo cada porção um núcleo distinto, como na figura3.

Figura 2 - Esquema de relação núcleo- satélite

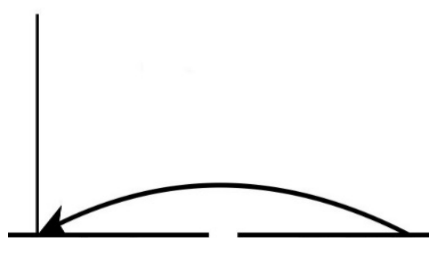

Figura 3 - Esquema de relação multinuclear

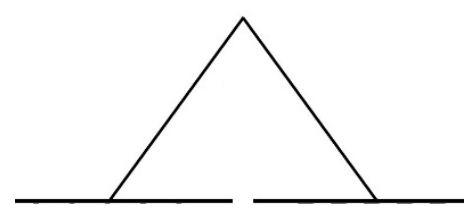

Esses dois esquemas, representados pelas figuras 2 e 3, são padrões propostos pela RST como pré-definidos que especificam de que modo porções do texto se relacionam para formar porções maiores ou o texto todo. Para a RST, o primeiro passo na análise do texto é dividi-lo em porções textuais que podem ser constituídas por orações ou porções maiores de texto. O próximo passo é identificar as relações a partir das seguintes condições: a) Restrições sobre o núcleo; b) Restrições sobre 
o satélite; c) Restrições sobre a combinação entre o núcleo e o satélite; d) Efeito.

Importa destacar que, para identificar as proposições relacionais, o analista baseia-se em julgamentos funcionais e semânticos, que têm como objetivo identificar a função de cada parte do texto e verificar como é produzido o efeito desejado em seu possível receptor. Esse julgamento feito pelo analista é baseado em princípios de plausibilidade, uma vez que ele tem acesso ao texto, tem conhecimento do contexto em que o texto foi produzido, das convenções culturais do produtor do texto e de seus possíveis receptores, porém não tem acesso direto ao produtor do texto ou aos possíveis receptores, por isso ele não pode afirmar que a análise está correta, pode apenas sugerir uma análise plausível (MANN \&THOMPSON, 1988).

Portanto, ressaltamos que os critérios utilizados na análise do gênero resposta argumentativa dizem respeito a julgamentos funcionais e semânticos que objetivam identificar a função de cada porção textual, bem como perceber o efeito que o texto produz em seu receptor. Nesse sentido, para descrever as relações que se estabelecem entre as orações, é determinante considerar a intenção comunicativa do enunciador, assim como a avaliação que este faz do enunciatário.

Ao analisarmos a atuação da função textual-discursiva das orações adverbiais, vamos ao encontro da proposta dos estudos da RST, uma vez que essa perspectiva tem seu embasamento na vertente funcionalista, que, além de priorizar a língua em uso, considera o texto objeto de estudo. Reconhecemos, portanto, em nosso trabalho, a relevância da RST à análise da estrutura retórica do gênero resposta argumentativa, ao evidenciar, então, o papel significativo de cada uma das partes coerentes desse gênero.

\section{A abordagem tradicional da articulação de orações}

Nesta seção, cabe revisitar conceitos sobre a articulação de orações do ponto de vista tradicional, entretanto, essa revisão não objetiva abarcar todos os teóricos da língua, mas apenas retomar os conceitos de alguns deles, a fim de oferecer uma reflexão para possibilitar um melhor entendimento da proposta que será discutida no decorrer deste estudo que objetiva oferecer novos estudos sobre o processo de articulação de orações.

Na articulação de orações, segundo os conceitos da abordagem 
V. 6 (2)

29-53

jul/dez

2016

tradicional, resultam relações de igualdade sintática ou de dependência sintática, ou seja, relações de coordenação ou de subordinação, respectivamente. Para a vertente tradicional, a coordenação e a subordinação são processos sintáticos analisados dentro do período composto. Nesse período, podem ocorrer três tipos básicos de orações: principal, subordinada e coordenada.

Cunha (1972) defende que a coordenação se constitui de orações independentes, ou seja, cada uma tem sentido próprio e não funcionam como termos de outra oração, apenas, uma pode enriquecer com o seu sentido a totalidade da outra. "Às orações autônomas dá-se o nome de coordenadas, e o período por elas formado diz-se composto por coordenação." (CUNHA, 1972, p. 343, grifos do autor).

As orações subordinadas são classificadas como termos essenciais, integrantes ou acessórios de outra oração. Cunha (1972), assim como Rocha Lima (1979), considera os critérios semânticos para conceituar a coordenação e os sintáticos para a subordinação. Segundo esse último, "no período composto por subordinação, há uma oração principal, que traz presa a si, como dependente, outra ou outras. Dependentes, porque cada uma tem seu papel como um dos termos da oração principal" (ROCHA LIMA, 1979, p. 232).

Ao rever os conceitos de coordenação e de subordinação, Bechara (2006) usa o termo hipotaxe ao tratar da subordinação e a define como um fenômeno de estruturação de camadas gramaticais em que uma das orações passa a funcionar como membro de outra camada inferior e, desse modo, funciona como membro sintático da outra. Assim, segundo esse autor, a hipotaxe

[...] é a propriedade oposta à hipertaxes: consiste na possibilidade de uma correspondente a um estrato superior poder funcionar num estrato inferior, ou em estratos inferiores. É o caso de uma oração passar a funcionar como "membro" de outra oração, particularidade muito conhecida em gramática (BECHARA, 2006, p.47).

Sobre as coordenadas, esse autor usa o termo parataxe e explica que são sintaticamente independentes. Conforme Bechara (2006), esse tipo de articulação consiste

5 "[...] a hipertaxe é a propriedade pela qual uma unidade de um estrato inferior pode funcionar por si só - isto é, combinando-se com zero - em estratos superiores, podendo chegar até ao estrato do texto e aí opor-se a unidades próprias desse novo estrato. Assim, um monema pode, em princípio, funcionar como palavra; uma palavra como grupo de palavras, e assim sucessivamente." (BECHARA, 2006, p. 46). 
[...] na propriedade mediante a qual duas ou mais unidades de um mesmo estrato funcional podem combinar-se nesse mesmo nível para constituir, no mesmo estrato, uma nova unidade suscetível de contrair relações sintagmáticas próprias das unidades simples desse estrato. [...] Portanto o que caracteriza a parataxe é a circunstância de que as unidades combinadas são equivalentes do ponto de vista gramatical, isto é, uma não determina a outra, de modo que a unidade resultante da combinação é também gramaticalmente equivalente às unidades combinadas (BECHARA, 2006, p.48).

Interessante é, pois, observar que a abordagem tradicional da articulação de orações baseia-se na classificação das orações de acordo com suas funções sintáticas e semânticas, desconsiderando o componente pragmático; e o estudo limita-se ao nível da frase, isto é, a tradição gramatical apresenta para a descrição do período composto uma visão que considera a noção de dependência ou independência entre suas partes, com conceituações que nem sempre atendem à funcionalidade oracional discursiva.

\section{Abordagem funcionalista da articulação de orações}

Para Neves (2010), uma investigação de base funcionalista entra na organização dos enunciados para avaliá-los considerando sempre os componentes sintático, semântico e pragmático. Além disso, para essa autora, a abordagem funcionalista tem como proposta questionar o corte entre as tradicionais categorias subordinação e coordenação. Ainda, conforme Neves:

[...] nesse amplo bloco de construções complexas o termo subordinação não pode ser simplesmente e indiscriminadamente definido como designador de construções em que uma oração exerce função sintática em outra (NEVES, 2010, p. 229).

De acordo com a visão dessa autora, pode-se inferir que, dentro do estudo da organização e da articulação de orações em uma perspectiva funcionalista, devem ser levados em conta elementos sintáticos semânticos e pragmáticos. Assim, a preocupação em descrever a relação entre as orações no nível do discurso ${ }^{6}$, segundo Decat (1999), tem levado estudiosos a abandonar o termo "subordinação" e examinar o fenômeno da articulação de orações. A esse respeito Decat, assim se expressa

6 O termo discurso está sendo tomado aqui "como todo e qualquer produto da atividade de linguagem numa situação real de comunicação" (DECAT, 1995, p. 20). 
v. 6 (2) 29-53 jul/dez 2016

[...] a sintaxe No discurso, e não em sentenças isoladas, pode fornecer subsídios para uma melhor compreensão sobre a estrutura do discurso, através da investigação desse aspecto que contribui para a organização discursiva coerente e coesiva, que é a hipotaxe adverbial [...] (DECAT, 1999, p. 300, grifo original)

Decat (1999) ressalta que o uso de termos como subordinação e dependência evidencia a inadequação desse estudo para a compreensão da natureza da hipotaxe adverbial. E acrescenta que

[...] Mesmo análises linguísticas mais modernas, trabalhando com essas noções dentro de um continuum, ou sob o parâmetro da integração estrutural de uma cláusula em outra, mostraramse insuficientes por não abrirem a possibilidade de se dar conta da função a que uma cláusula adverbial serve numa porção maior de discurso [...] (DECAT, 1999, p. 302)

Decat (2010) considera um problema as classificações hipotáticas se resumirem a um número fixo de relações. Na Nomenclatura Gramatical Brasileira (NGB), por exemplo, ao se tratar a respeito das hipotáticas adverbiais, menciona-se um número limitado de orações. Matthiessen e Thompson, por sua vez, propõem que "a combinação de orações reflete a organização retórica do discurso", assim:

[...] relações como as de causa, condição, concessão, etc. são relações retóricas que existem entre quaisquer partes de um texto, e que podem gramaticalizar-se na combinação de orações, seja na relação de listagem (o correspondente à parataxe, em que os membros têm o mesmo estatuto), seja na relação núcleo-satélite (o correspondente à hipotaxe, em que um membro do par é 'ancilar' do outro, isto é, dependente de outro, numa relação que envolve a noção de 'satélite' e a noção de 'âmbito de incidência') (MATTHISSEN; THOMPSON apud NEVES, 2010, p. 229).

Desse modo, torna-se relevante, então, empreender uma análise que, além de estar centrada nas relações mantidas entre as cláusulas que se articulam hipoteticamente, faça um exame das funções discursivas a que elas estejam servindo (DECAT, 1999, p.310).

\section{Materialização e funções textual-discursivas da hipotaxe adverbial}

Decat (2009) explica que várias são as funções textual-discursivas que estão na base do uso das orações hipotáticas adverbiais, pois, além de exibirem a relação semântica como tempo, modo, causa/motivo, concessão, condição etc., elas exercem funções textual-discursivas 
como guia, foco, tópico, moldura, ponte de transição, dentre outras, que podem propiciar o entendimento da intenção do usuário da língua ao fazer as combinações entre as orações na organização do texto (DECAT, 2009, p. 116). Essa autora já havia apontado, em Decat (1999), para o fato de que

[...] as adverbiais parecem formalmente dependentes, mas têm uma independência organizacional. Ora, isso leva à conclusão de que, se se pensar em termos pragmáticos, todo enunciado é dependente, já que ele requer contexto para a sua interpretação - ou, em outros termos, já que ele é o produto de uma atividade de enunciação. Essa dependência pragmática será, pois, definida em termos do contexto e das relações que nele mantêm as proposições (DECAT, 1999, p. 302).

Decat (1999) defende que as orações adverbiais são opções organizacionais, pois o uso delas depende dos objetivos comunicativos do produtor de um determinado evento comunicativo. Assim, a partir das intenções comunicativas do falante é que serão determinadas as funções textual-discursivas.

Decat (2009) argumenta que a combinação de orações não se dá necessariamente entre cláusulas adjacentes. Por exemplo, uma cláusula adverbial pode estar relacionada com outra bem anterior no texto, ou se relacionar com o discurso subsequente, à maneira de "guias" ou guidepost. Sobre esse tema, Chafe (1984), ao utilizar o termo guidepost (guia), sugere que determinadas orações adverbiais presentes em alguns enunciados servem como "guia" para o interlocutor no discurso, sinalizando um caminho de orientação para as informações seguintes.

Decat (2009) explica que a hipotaxe adverbial poderá servir a uma função tópica, funcionando como ponto de partida para a estruturação da informação. Assim a hipotaxe adverbial na combinação entre as porções textuais, ao ocorrerem no início, serve à função tópica.

Nesse sentido, elas podem evidenciar a intenção do produtor do texto ao construir sua argumentatividade por meio das funções textualdiscursivas da hipotaxe adverbial, ao servirem de ponto de partida para a estruturação da informação do que vem expressa na porção nuclear. São comuns, nessa função tópica, a hipotaxe adverbial de condição, de motivo e de tempo.

Decat (2009) ressalta que, por razões pragmáticas, o produtor do texto pode desconsiderar o posicionamento de uma oração ao atribuir foco a determinada porção textual; a hipotaxe adverbial pode constituir, nesse sentido, uma forma de avaliação por parte do falante/produtor 
V. 6 (2) 29-53 jul/dez 2016

sobre o que vem expresso na porção do núcleo, em especial, quando posposta a esse núcleo.

Essa autora defende que a hipotaxe adverbial concessiva sustentada pela relação tese-antítese contribui para a argumentação do discurso e, por meio dessa articulação de orações, o falante pode fazer uma avaliação sobre o que vem expresso na porção central.

Assim como Decat (2009), Neves (2000) também constatou a função discursiva da hipotaxe adverbial a exemplo das concessivas, em que essas construções são essencialmente argumentativas; e, para essa autora, a ordem das construções concessivas obedece aos propósitos comunicativos:

Vistas de um ponto de vista pragmático, as concessivas indicam que o falante pressupõe uma objeção à sua asserção, mas que a objeção é por ele refutada, prevalecendo a sua asserção. O que está implicado, aí, é que, nas construções concessivas como nas condicionais - existe uma hipótese, que, no caso das concessivas, é a hipótese de objeção por parte do interlocutor (NEVES, 2000, p. 874).

De acordo com essa autora, as concessivas antepostas carregam informação mais conhecida do interlocutor, isto é, essas orações ocupam uma posição mais tópica. Nesse sentido, a autora remete ao princípio geral do processo comunicativo, defendido pela vertente funcionalista, quanto às informações mais conhecidas aparecerem em posições mais topicalizadas ao passo que as informações novas, tendem a aparecer em posições secundárias.

A par desse principio, podemos destacar o posicionamento de Givón (1995), em que a hipotaxe, quando posposta à oração-núcleo, codifica informação nova. Para esse autor, no geral, os efeitos da posição da oração do tipo adverbial em relação à nuclear (anteposta, intercalada, posposta) se inserem no domínio pragmático-discursivo, servindo a uma função de ponte de transição.

A par das considerações sobre as funções textual-discursivas dos autores acima citados, estão as de Thompson (1985), segundo as quais a adverbial de propósito anteposta tem a função de apresentar um problema e criar uma expectativa de solução.

Eu sugiro que uma oração adverbial de propósito anteposta forneça um quadro no qual a oração principal possa ser interpretada, e que isso ocorra por meio da sua função como conector numa corrente de expectativa - uma cadeia que está ligada da seguinte forma: 1. O ambiente, incluindo o próprio texto, bem como o conhecimento que o leitor traz a ele, cria 
um conjunto de expectativas. 2. Dentro deste conjunto de expectativas, há um problema, tanto porque eles podem se identificar com os objetivos dos participantes da história, ou porque eles têm seus próprios objetivos. 3. A oração de propósito indica esse problema e ainda suscita algumas expectativas sobre a sua solução (THOMPSON, 1985, p. 61, tradução nossa7).

Como se pode observar, para essa autora, a adverbial de propósito anteposta fornece um quadro em que a porção núcleo pode ser interpretada, ao criar um conjunto de expectativas a partir da porção textual precedente e do conhecimento partilhado dos interlocutores, isto é, dentro desse conjunto de expectativas, cria-se não só um problema, como também uma expectativa de solução para esse problema.

Uma vez apresentada a revisão geral dos princípios mais importantes do funcionalismo, de algumas das abordagens funcionalistas sobre o processo de articulação de orações, seguidos dos principais pressupostos da RST, dar-se-á início à revisão teórica sobre os gêneros do discurso, em especial, ao gênero resposta argumentativa.

\section{Gêneros do Discurso}

Ao refletir sobre os gêneros discursivos, Bakhtin (2000) ressalta que o uso da língua se processa por enunciados orais e escritos, produzidos pelos integrantes de uma determinada esfera discursiva. Assim, podemos compreender que, para esse autor, o enunciado reflete suas condições específicas e seus objetivos, pelo conteúdo, pelo seu estilo verbal, pelos recursos lexicais, fraseológicos e gramaticais e, especialmente, pela construção composicional. "Cada esfera de utilização da língua elabora seus tipos relativamente estáveis de enunciados, sendo isso o que denominamos gêneros do discurso" (BAKHTIN, 2000, p. 279).

Nessa perspectiva, de acordo com esse autor, as relações entre linguagem e sociedade são indissociáveis das diferentes esferas da atividade humana, entendidas como domínios discursivos (jurídico, religioso, educacional, jornalístico), que dialogam entre si e produzem, em cada esfera, formas relativamente estável de enunciados.

7 "I suggest that an initial purpose clause provides a framework within which the main clause can be interpreted, and that it does this by means of its role as a link in an EXPECTATION CHAIN - a chain that is linked as follows: 1. The environment, including the text itself, as will as the knowledge which the reader brings to it, creates a set of expectations. 2. Within this set of expectations a problem, either because they can identify with the goals of the story participants, or because they have their own goals. 3. The purpose clause names this problem and raises further expectations about its solutions.". 
v. 6 (2) 29-53 jul/dez 2016

Ainda de acordo com Bakhtin (2000), os gêneros discursivos são histórica e socialmente construídos, uma vez que se relacionam diretamente às diferentes situações comunicativas que, por sua vez, os determinam com características temáticas, composicionais e estilísticas. Segundo o autor,

[...] o enunciado reflete as condições específicas e as finalidades de cada esfera, não só por seu conteúdo (temático) e por seu estilo verbal, ou seja, pela seleção operada nos recursos da língua - recursos lexicais, fraseológicos e gramaticais -, mas também, e, sobretudo, por sua construção composicional (BAKHTIN, 2000, p. 279).

Em se tratando dos elementos que constituem o gênero, convém salientar que o conteúdo temático não se refere ao assunto específico de um texto, mas à finalidade discursiva, um domínio de sentido de que se ocupa o gênero (orientação de sentido para o próprio discurso e os participantes durante o evento comunicativo).

A construção composicional diz respeito ao modo de organizar o texto, de estruturá-lo e é responsável pelo acabamento da unidade de comunicação verbal, possibilitando ao interlocutor inferir a totalidade da estrutura do gênero, isto é, refere-se ao tipo de relação dos participantes da comunicação verbal (com o ouvinte, com o leitor, com o interlocutor, com o discurso do outro).

Já o estilo é uma seleção de meios linguísticos, ou seja, seleção de recursos lexicais, fraseológicos e gramaticais da língua, em função da imagem do interlocutor e de como se presume sua compreensão responsiva ativa do enunciado. Entretanto, os estudos bakhtinianos priorizam o processo de produção dos gêneros do discurso ao defini-los (uma vez que aquele autor afirma que a constituição e o funcionamento do gênero se relacionam mais a uma situação social de interação).

Como se observa, Bakhtin (2000) defende a importância tanto das propriedades formais da língua, quanto do papel do locutor no uso e na construção dos sentidos. Por esse viés, os gêneros do discurso podem ser compreendidos, de modo geral, como o uso particular do discurso em função das mais diversas situações de interação social e comunicativa.

Dessa forma, entendemos que há uma infinidade de gêneros discursivos, uma vez que eles surgem da real necessidade de interação entre os indivíduos a partir do uso efetivo da língua e se ampliam de acordo com o desenvolvimento dos domínios discursivos. 
Ainda de acordo com a perspectiva bakhtiniana, os pesquisadores do grupo de Genebra ${ }^{8}$, a partir da teoria sobre os gêneros do discurso, baseando-se no pressuposto de que se comunicar oralmente e por escrito pode e deve ser ensinado sistematicamente, apresentam a proposta de se agrupar os gêneros organizando-os em cinco domínios, quais sejam, os agrupamentos da ordem (a) do relatar; (b) do narrar; (c) do argumentar; (d) do expor; (e) do descrever ações.

Dentre tais agrupamentos, elegeu-se, para esta pesquisa, o que trata especificamente dos gêneros ligados à argumentação. Nesse sentido, reconhecemos que o trabalho com gêneros textuais é de fundamental importância para quem pretende entender a língua e seus usos, visto que esses gêneros variam e se modificam de acordo com as mudanças na língua.

\section{O Gênero Resposta Argumentativa}

O corpus deste trabalho é constituído por um material que abrange os gêneros textuais da ordem do argumentar. Assim, torna-se relevante conceituar o que vem a ser o gênero resposta argumentativa. Sobre a estruturação do gênero textual e considerando a finalidade com que o gênero resposta argumentativa é frequentemente apresentado, convém destacar os estudos de Garcia (1985), que apresentam uma valiosa contribuição sobre a construção de textos argumentativos. Para esse autor, o parágrafo é a unidade da composição, o que significa que sua organização é essencial para a estruturação do texto.

Garcia (1985) propõe que a organização de um texto seja constituída por um ou dois períodos curtos iniciais, o tópico frasal, que é a introdução da unidade de composição, a qual fornece o tema a ser desenvolvido; e o parágrafo-padrão apresenta a seguinte estrutura: (a) introdução - também denominada tópico frasal, é constituída de uma ou duas frases curtas, que expressam, de maneira sintética, a ideia principal do parágrafo, definindo seu objetivo; (b) desenvolvimento corresponde a uma ampliação do tópico frasal, com apresentação de

8 O grupo de pesquisadores da chamada "Escola de Genebra" - composto por JeanPaul Bronckart, Bernard Schneuwly, Joaquim Dolz, A. Pasquier, Sylvie Haller, entre outros - pertence ao Departamento de Didática de Línguas da Faculdade de Psicologia e Ciências da Educação (FAPSE) da Universidade de Genebra (UNIGE) e dedica suas pesquisas tanto à constituição do interacionismo sócio-discursivo quanto a sua aplicação ao ensino de francês como língua materna. Essa equipe tem, desde os anos 80 , realizado trabalhos na tentativa de modificar algumas práticas de ensino vistas como "tradicionais" e repensar a questão da formação dos professores de língua materna (ROJO, 2005). 
V. 6 (2)

29-53

jul/dez

2016

ideias secundárias que o fundamentam ou esclarecem; (c) conclusão - nem sempre presente, especialmente nos parágrafos mais curtos e simples, a conclusão retoma a ideia central, levando em consideração os diversos aspectos selecionados no desenvolvimento.

Da relação entre a argumentação e os traços característicos do gênero resposta argumentativa, e desse gênero com a função textualdiscursiva da hipotaxe adverbial, emerge a relação tanto com a forma, quanto com a função, haja vista que tanto a argumentação, quanto o gênero concebem a linguagem como um instrumento de interação social, investigando a maneira pela qual o falante usa a língua para atingir seus propósitos comunicativos.

Por esse viés, ressaltamos que, para efeito de análise, tomaremos o tópico frasal como resposta à pergunta do comando das produções textuais que integram nosso corpus, visto que, segundo Garcia (1985), é nessa porção textual que a ideia principal do parágrafo deve ser apresentada, definindo o objetivo comunicativo do produtor do gênero.

Às considerações sobre os estudos do gênero textual, Decat (2008) propõe a relação entre forma e função: "As formas recorrentes num determinado gênero, ou em um grupo de gêneros, servem à caracterização do gênero, na medida em que elas são uma decorrência dos objetivos sociocomunicativos do próprio gênero." (DECAT, 2008, p.170), isto é, essa autora parte do princípio de que a forma é efeito da função. Dessa maneira, perpassa por este trabalho a ideia de que os meios linguísticos são reflexos de sua função num determinado contexto comunicativo e, para tanto, reivindicamos a relevância tanto das postulações funcionalistas aqui apresentadas, quanto dos estudos sobre a organização dos gêneros textuais para atingir os objetivos do presente estudo.

\section{A constituição do corpus}

O corpus deste trabalho é constituído por produções textuais do gênero resposta argumentativa que foram mais bem avaliados pela Banca de Avaliação de Redação do Vestibular de Verão de 2011 da Universidade Estadual de Maringá (UEM). Como proposta de produção de um dos gêneros exigidos pela prova de redação da Universidade Estadual de Maringá (UEM), os candidatos tiveram de elaborar uma resposta à seguinte pergunta: "Como morador (a) de república, redija, em até 15 linhas, uma resposta argumentativa à pergunta: Morar em 
república é ou não uma experiência enriquecedora?".

Primeiramente, fizemos um recorte constituído por cem produções textuais para esta pesquisa. Posteriormente, procedemos à quantificação das ocorrências das orações adverbiais e suas posições no texto, a fim de observar a recorrência dessas orações no recorte, com o objetivo de analisar se as funções textual-discursivas das orações adverbiais podem contribuir para a construção da argumentatividade do gênero resposta argumentativa.

\section{Exercício de análise}

Nesta seção, apresentam-se os resultados encontrados na análise das funções textual-discursivas materializadas pelas orações adverbiais. Primeiramente, analisam-se os resultados obtidos a partir da aplicação dos fatores no cruzamento entre o tipo de construção e a função textual-discursiva materializada pela hipotaxe adverbial.

Sobre o fator Tipo de construção x Função textual-discursiva, as hipóteses levantadas nesta pesquisa nos permitem vislumbrar a possibilidade da ocorrência da hipotaxe adverbial estar diretamente ligada à intenção do falante em enfatizar sua intenção comunicativa, isto é, partimos da hipótese de que não só a função textual-discursiva das orações adverbiais, mas também as relações retóricas que delas emergem contribuem para a construção da argumentação do gênero resposta argumentativa. Assim, a análise a ser desenvolvida na sequência procederá no sentido de evidenciar quais foram as funções textual-discursivas desempenhadas pela hipotaxe adverbial.

Gráfico 1 - Função Textual-Discursiva x Tipo de Construção

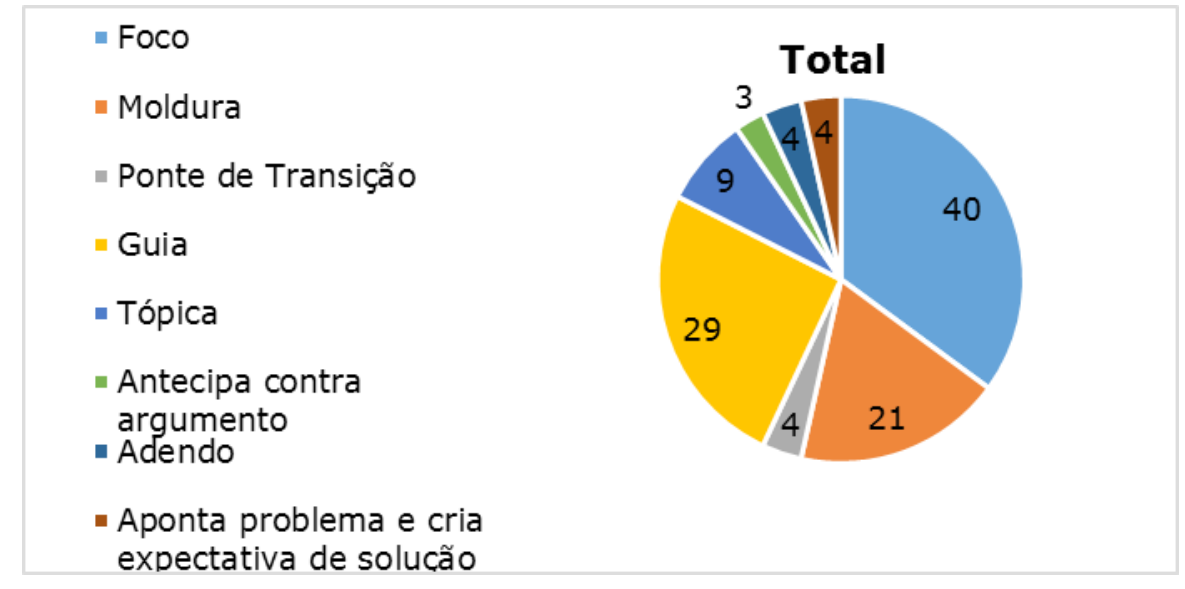


v. 6 (2)

29-53

jul/dez

2016

Conforme expõe o Gráfico 1, no decorrer do cruzamento dos fatores tipo de construção e função textual-discursiva, encontramos 40 ocorrências da função focal a serviço da argumentação. Dentre essas ocorrências, 31 foram realizados pela hipotaxe adverbial de causa e 9 pelas orações hipotáticas de condição. Decat (2009) explica que, por razões pragmáticas, o produtor do texto pode não considerar o posicionamento de uma oração ao atribuir foco em uma determinada porção textual, pois a hipotaxe adverbial pode constituir, nesse sentido, uma forma de avaliação/argumentação/realce por parte do falante/produtor sobre o que vem expresso na porção do núcleo, em especial, quando posposta a esse núcleo. Vejamos em (1) um exemplo para ilustrar essa função.

(1) "Morar em república é uma experiência extremamente enriquecedora, pois me deu oportunidade de sair da minha zona de conforto." (grifo nosso).

No decorrer da coleta e cruzamento dos dados, encontramos 21 orações hipotáticas temporais a serviço da função de moldura. Dentre essas ocorrências, temos o exemplo (2).

(2) "Morar em república é uma experiência enriquecedora. Me tornei um morador de república logo quando entrei na faculdade, aos 19 anos.". (grifo nosso).

Como se pode observar, essa amostra da hipotaxe adverbial temporal evidencia a função de moldura. De acordo com os estudos de Decat (2009), esse satélite adverbial apresenta a informação que o produtor considera necessária à compreensão entre as porções textuais.

No exemplo em (2), a hipotaxe adverbial temporal cria um quadro/moldura ao limitar a informação que o falante/produtor do texto considera necessária à compreensão da informação que está contida na porção nuclear "... logo quando entrei na faculdade..." por fornecer informações que marcam um evento/asserção circunstancialmente, e, do ponto de vista semântico, a hipotaxe adverbial temporal serve a essa função-textual discursiva.

Para Decat (2009), além dessa função de moldura, a hipotaxe adverbial temporal ainda poderá servir, às vezes, como ponte de transição, em função anafórica e catafórica simultaneamente (DECAT, 2009, p. 116). Vejamos o exemplo (3): 
(3) "Morar em república nos proporciona uma ampliação no nosso horizonte de ideias e na maneira como percebemos o mundo, por vivermos com pessoas de diferentes origens, opiniões e hábitos. Ao termos de conviver com as diferenças passamos a enxergá-las com outros olhos e até mesmo a incorporá-las." (grifo nosso).

De acordo as ocorrências expostas, em se tratando de função anafórica e catafórica simultaneamente, evidenciamos no nosso corpus de análise cinco exemplos da hipotaxe adverbial temporal anteposta ao núcleo, em que essa posição inicial remete ao discurso precedente e subsequente funcionando como ponte de transição entre as porções textuais, como podemos observar pela exposição do exemplo (3) "Ao termos de conviver."

No decorrer da tabulação entre o tipo de construção x função textual-discursiva, encontramos 29 ocorrências da hipotaxe adverbial temporal servindo à função de guia para o leitor, conforme se pode verificar em (4).

\section{(4) "Ao sair da casa dos pais o estudante adquire} responsabilidades - como a de pagar contas - e aprende a dar seus passos sozinhos." (grifo nosso).

As orações hipotáticas adverbiais temporais em posição anteposta ao núcleo servem à função textual discursiva de guia, função denominada por Chafe (1984) de guidepost. De acordo com esse autor, as construções hipotáticas adverbiais na função de guidepost fornecem ao leitor uma orientação para as informações seguintes. Por esse viés, esclarecemos que, no decorrer da tabulação dos dados, todas as orações temporais em situação de guia para o leitor, por ocorrerem no início da porção textual, direcionam o interlocutor ao discurso subsequente, delimitando, dessa forma, a informação, como podemos constatar por meio dos exemplos tabulados.

Importa destacar que as orações hipotáticas adverbiais temporais, ao organizarem o discurso em posição inicial do texto, podem materializar uma sobreposição de funções, como as de guia para o leitor, conforme vimos pela ocorrência em (4), e a função tópica. Nesta última, a hipotaxe adverbial pode funcionar como ponto de partida para a estruturação da informação. O exemplo em (5) a seguir ilustra bem essa função. 
V. 6 (2)

29-53

jul/dez

2016
(5) "Quando se convive com pessoas diferentes de você, de nós em vários aspectos, sempre existem lições a serem aprendidas." (grifo nosso).

De acordo com os dados do gráfico 1, identificamos 9 ocorrências da hipotaxe adverbial que serviram à função tópica. Ao ocorrerem no início da porção textual, podem evidenciar a intenção do produtor do texto, servindo para a construção da argumentação por meio da função textual-discursiva materializada pela hipotaxe adverbial condicional, pois essa função serve de ponto de partida para a estruturação da informação do que vem expresso na porção nuclear, revelando-se, assim, como uma opção organizacional do discurso.

Dentre as 9 ocorrências da função tópica desempenhada pelas construções condicionais, ressaltamos que, em 4 delas, identificamos a hipotaxe adverbial com leitura temporal-condicional, como se pode evidenciar em(6):

(6) "Quandodotados deregras, de divisão de responsabilidades, de auxílio mútuo, creio que repúblicas podem se tornar verdadeiras escolas." (grifo nosso)

No caso das construções concessivas, no cruzamento dos dados, encontramos 3 ocorrências em posição anteposta ao núcleo. A esse respeito, vejamos o exemplo (7)

(7) "Apesar do receio de sair de casa e morar com outras pessoas, a convivência em uma república garante um imenso aprendizado para a vida." (grifo nosso).

Decat (2009) aponta que a hipotaxe adverbial concessiva sustentada pela relação tese-antítese contribui para a argumentação do discurso e, por meio dessa articulação de orações, o falante pode fazer uma avaliação sobre o que vem expresso na porção central, como exemplificamos em (8)

(8) "Apesar de ser preciso uma boa dose de compreensão, essa experiência de morar em uma república, te traz o sentimento de família com o grupo." (Grifo nosso). 
Sobre os estudos das concessivas, podemos complementá-los com as considerações de Neves (2000). De acordo com essa autora, essas construções são essencialmente argumentativas e a ordem das concessivas obedece aos propósitos comunicativos. Dessa forma, para essa autora, as concessivas antepostas carregam informação mais conhecida do interlocutor, ocupando uma posição mais tópica, em que se refuta uma possível ou previsível objeção do interlocutor e depois se faz uma asseveração. Para exemplificar essa afirmação, vejamos este exemplo:

(9) "Apesar de nada fácil, a vida em república foi um aprendizado que tive, e que continuo tendo, o qual será muito importante para toda a vida."

Pelos exemplos do gráfico, constatamos que as construções concessivas antepostas, ao anteciparem um contra-argumento e por constituírem-se como opções organizacionais no discurso, contribuem eficazmente aos propósitos comunicativos do falante/produtor do texto.

Para Neves (2000), quanto às construções concessivas pospostas, não se pode invocar a função de tópico discursivo, pois elas exercem a função de adendo. Nesse sentido, essa autora remete ao posicionamento de Givón (1995), em que a hipotaxe adverbial, quando posposta à oraçãonúcleo, codifica informação nova, isto é, para esse autor, no geral, os efeitos da posição da oração do tipo adverbial em relação à nuclear (anteposta, intercalada, posposta) se inserem no domínio pragmáticodiscursivo ao servir como recurso importante na argumentação do produtor, candidato.

O exemplo em (10) merece destaque, pois, ao analisá-lo, detectamos que ocorreu uma sobreposição de funções, visto que as ocorrências das construções concessivas pospostas, além de funcionarem como adendo ao acrescentarem uma informação nova ao contexto em forma de comentário/esclarecimento do autor, justificando-a, também serve à função focal.

Segundo Decat (2009), sob influência de pressões pragmáticas, o produtor de um texto pode desconsiderar o posicionamento de uma oração ao atribuir foco em uma determinada porção textual, pois essa oração pode constituir-se como uma maneira de avaliação/ argumentação/realce do falante/produtor sobre aquilo que vem expresso na porção nuclear, principalmente, quando posposta a essa porção. Sobre 
v. 6 (2) 29-53 jul/dez 2016

as concessivas funcionando com sobreposição de funções, vejamos:

(10) "As primeiras experiências surgem logo nos meses iniciais, apesar de serem novidade a todos". (grifo nosso).

Nesse sentido, portanto, evidenciamos que as construções concessivas quando pospostas ao núcleo têm importante função na argumentação do produtor/falante do texto, visto que acrescentam argumentos ao seu discurso.

Outra função textual-discursiva que encontramos no decorrer da tabulação dos dados foi a função de apresentar um problema e criar uma expectativa de solução para o que está contido na porção nuclear.

Conforme Thompson (1985), a adverbial de propósito anteposta fornece um quadro em que a porção do núcleo pode ser interpretada. E essa oração adverbial anteposta faz isso ao criar um conjunto de expectativas a partir da porção textual precedente e do conhecimento partilhado dos interlocutores e, dentro desse conjunto de expectativas, cria-se não só um problema, como também uma expectativa de solução. Para evidenciarmos essa função-textual, vejamos o exemplo (11).

(11) "Em nossa república para manter uma ordem fizemos tabelas as quais contém as despesas e como vamos dividilas, escalas de limpeza e até mesmo quem fica responsável pela comida" (grifo nosso).

Pode-se notar, pela exposição desse exemplo, que a porção textual que precede a adverbial de propósito anteposta cria um conjunto de expectativas em relação ao "problema de morar em uma república", do exemplo 11, como afazeres domésticos e, simultaneamente, a porção textual representada pela adverbial de propósito anteposta fornece um quadro em que o leitor deve interpretar esse conjunto de expectativas, encaminhando-o para uma solução do "problema" criado na porção anteposta à adverbial de propósito.

\section{Conclusão}

Este trabalho analisou, à luz do funcionalismo, funções textual-discursivas, como função tópica, foco, antecipação de contraargumento, adendo, função de apontar problema e criar expectativa de 
solução, função de ponte de transição, moldura e função de guia para o leitor que estão na base das orações hipotáticas adverbiais de condição, causa, concessão, propósito e temporal como recurso argumentativo do gênero resposta argumentativa.

Conforme procedimentos de análise, em relação ao cruzamento entre o fator Tipo de Construção e Função textual-discursiva no desenvolvimento dessa pesquisa, a análise demonstrou a predominância da função de foco desempenhada pelas construções hipotáticas de causa e condição. Essa função revela as intenções pragmáticas do produtor do texto, que, ao atribuir foco em uma determinada informação, pode desconsiderar o posicionamento de uma oração ou porção textual, pois a hipotaxe adverbial pode constituir-se como uma forma de avaliação/ argumentação/realce por parte do falante/produtor sobre.

A função de guia para o leitor também foi recorrente e materializou-se juntamente com outras funções, como moldura e ponte de transição, sendo a função de guia a segunda maior ocorrência das funções textuais discursivas desempenhadas pelas construções hipotáticas temporais. A função de guia para o leitor fornece uma orientação para as informações seguintes e a de moldura marca um evento, uma asserção circunstancialmente. Por sua vez, a função de ponte de transição estabelece um elo entre o discurso precedente e o subsequente.

Ao término desta pesquisa, por meio dos resultados obtidos a partir do cruzamento dos fatores Tipo de construção e Função textualdiscursiva, atingiu-se o objetivo inicial de identificar se essas funções, ao se estabelecerem entre as porções textuais, poderiam constituir-se como recurso argumentativo ao gênero resposta argumentativa, uma vez que as orações adverbiais são opções organizacionais, cujo uso depende dos objetivos comunicativos do produtor do discurso. Nesse sentido, constatamos que é a partir das intenções comunicativas do falante que serão determinadas as funções textual-discursivas da hipotaxe adverbial.

\section{Referências}

ANTONIO, Juliano. Desiderato. Estrutura retórica e articulação de orações em narrativas orais e em narrativas escritas do português. Araraquara, 2004. Tese (Doutorado em Linguística e Língua Portuguesa). Faculdade de Ciências e Letras, UNESP, Araraquara, 2004.

BAKHTIN, M. Estética da Criação Verbal. Trad. Paulo Bezerra. 4 ed. São Paulo: Martins Fontes, 2000. 
V. 6 (2) 29-53 $\mathrm{jul} / \mathrm{dez}$ 2016

BECHARA, Evanildo. Moderna gramática portuguesa. Rio de Janeiro: Lucerna, 2006.

BUTLER, C. Functional approaches to language. In: BUTLER, C.; GÓMEZ GONZÁLEZ, M.L.A.; DOVAL-SUÁREZ, S.M. (eds) The Dynamics of Language Use: Functional and Contrastive Perspectives. Amsterdam and Philadelphia: Jonh Benjamins, 2005, p. 3-17.

CALICCHIO, F. C. A Função Textual-Discursiva da Hipotaxe Adverbial no Gênero Resposta Argumentativa. 100 f. Dissertação (Mestrado em Estudos Linguísticos) Departamento de Pós-Graduação em Letras. Universidade Estadual de Maringá, Maringá, 2014.

A Função Textual- Discursiva da Hipotaxe Adverbial no Gênero Resposta Argumentativa. IX EPCC - Encontro Internacional de Produção Científica Unicesumar. 03 a 06 de novembro de 2015, Maringá - Paraná Brasil. Disponível em< http://www.cesumar.br/prppge/pesquisa/epcc2015/ anais/fatima_christina_calicchio.pdf> Acesso em 12/09/2016.

CHAFE, W. L. How People Use Adverbial Clauses. In: Proceedings of the Tenth Annual Meeting of the Berkeley Linguistics Society, pp. 437-449. Disponível em: http://linguistics.berkeley.edu/bls/, 1984.

CUNHA, Celso. Gramática do português contemporâneo. Rio de Janeiro: Nova Fronteira, 1972.

DECAT, Maria Beatriz Nascimento. Uma abordagem funcionalista da hipotaxe adverbial em português. Revista SériEncontros (Descrição do português: abordagens funcionalistas), Araraquara, SP, Unesp, ano XVI, n. 1., p. 299318, 1999.

A Relevância da investigação dos processos linguísticos, numa abordagem funcionalista, para os estudos sobre os gêneros textuais. In: ANTONIO, J. D. (Org.). Estudos descritivos do português: história, uso e variação. São Carlos: Editora Claraluz, 2008.

A hipotaxe adverbial em português: materializações e funções textual-discursivas. In: SIMPOSIO MUNDIAL DE ESTUDOS DE LINGUA PORTUGUESA (II SIMELP), II, Évora, 2009. Anais... Évora, 2009, p. 113-121.

Relações retóricas e funções textual-discursivas na articulação de orações no português brasileiro em uso. Revista Calidoscópio, Rio Grande do Sul, Unisinos, vol. 8, n. 3, p. 167-173, 2010. 1995 .

DIK, S. The theory of functional grammar. Dodrecht: Foris, 1989.

The theory of functional grammar. Part II: Complex and derived constructions. N.York: Mouton de Gruyter, 1997.

GARCIA, O. M. Comunicação em prosa moderna. Rio de Janeiro: FGV, 1985.

GIVÓN,T. Functionalism and Grammar. Amsterdam/Philadelphia: John Benjamins Publishing Company, 1995.

HENGEVELD, K. The architecture of a Functional Discourse Grammar. 
In: MACKENZIE, J. L.; GÓMEZ-GONZÁLEZ, M. Á. A new architecture for Functional Grammar (Functional Grammar Series 24). Berlin: Mouton de Gruyter, 2004.

Dynamic expression in Functional Discourse Grammar. In: GROOT,

C.; HENGEVELD, K. Morphosyntactic expression in Functional Grammar (Functional Grammar Series 27). Berlin: Mouton de Gruyter, 2005.

HENGEVELD, K.; MACKENZIE, L. Functional Discourse Grammar: a typologically-based theory of language structure. Oxford: Oxford University Press, 2008.

MANN W. C.; THOMPSON. S. A. Relational proposition in discourse. California: University of Southern, 1983.

.; THOMPSON, S. A. Rhetorical Structure Theory: toward a functional theory of text organization. Text - Interdisciplinary Journal for the Study of Discourse, v. 8., n. 3, p. 243-281, 1988.

.; MATTHIESSEN, C. M. I. M.; THOMPSON, S. A. Rhetorical Structure Theory and text analysis. In: MANN, W. C.; THOMPSON, S. A. (eds.) Discourse description: diverse linguistic analyses of a fund-raising text. Amsterdam/ Philadelphia: J. Benjamins, 1992, p. 39-77.

MARTELOTTA, Mário Eduardo. Manual de linguística. (Org.). 1. ed. São Paulo: Contexto, 2009.

MATTHIESSEN, C.; \& THOMPSON. S.A. The structure of discourse and 'subordination'. In: HAIMAN, J.; THOMPSON, .S. A. Clause combining in Grammar and Discourse. Amsterdam: John Benjamins, 1988, p. 275-329.

NEVES, M. H. M. A gramática funcional. São Paulo: Martins Fontes, 1997. Gramática de usos do português. São Paulo: Editora Unesp, 2000. Unesp, 2002.

A gramática: história, teoria e análise, ensino. São Paulo: Editora Texto e gramática. São Paulo: Contexto, 2010.

ROCHA LIMA, Carlos Henrique da. Gramática normativa da língua portuguesa. 15. ed. Rio de Janeiro: José Olympio, 1979.

ROJO, R. Gêneros do Discurso e Gêneros Textuais: Questões Teóricas e Aplicadas. In: MEURER, J.L.; BONINI, A.; MOTTA-ROTH, D. (Orgs). Gêneros: teorias, métodos e debates. São Paulo: Parábola Editorial, 2005, p. 184-207.

THOMPSON, S. Grammar and written discourse: initial vs. final purpose clause in English. Text - Interdisciplinary Journal for the Study of Discourse, v. 5. p. $55-84,1985$.

Recebido em: 05 de jul. de 2016.

Aceito em: 10 de set. de 2016. 